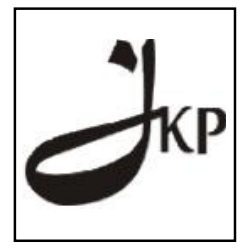

Jurnal Konseling dan Pendidikan

ISSN Cetak: 2337-6740 - ISSN Online: 2337-6880

http://jurnal.konselingindonesia.com

Volume 1 Nomor 1, Februari 2013, HIm 6-9

\title{
Permasalahan Anak Asuh dan Aplikasi Pelayanan Konseling Terhadap Mereka
}

\author{
Yusida Imran ${ }^{1 *}$ \\ ${ }^{1}$ Sekolah Tinggi Agama Islam (STAI) YKI Sumatera Barat
}

\begin{abstract}
Abstratc
The research is conducted by means of descriptive qualitative method. The subjects of this research all of the YAB orphans those are 25 children altogether. The research instruments are AUM-U 1,2 and 5, questionnaire as well as a documentation study. The data obtained are analyzed and described. The research findings show that (1) the problems that the orphans mainly face relate to their personal matters, career and jobs; (2) there are 9 types of counseling service that can be provided at YAB. However, those already provided service are information service and individual counseling service; (3) counseling services play significant roles in building the orphans' self confidence, minimizing their psychological burden and solving their problems. Therefore, the writer recommends that the Foundation (YAB) utilize counseling services as one of the prioritized activities for handling orphans problems at $Y A B$.
\end{abstract}

Keyword: pelayanan konseling, anak asuh, yayasan Asrul Bakar.

Copyright (C) 2013 IICE - Multikarya Kons - All Rights Reserved

Indonesian Institute for Counseling and Education (IICE) Multikarya Kons

\section{PENDAHULUAN}

Pendidikan adalah salah satu dari wujud peradapan bangsa, upaya untuk mencapai tujuan pendidikan bukanlah suatu yang mudah. Banyak ditemukan berbagai masalah di lapangan, baik masalah di rumah, di sekolah maupun di lingkungan sosial masyarakat, bahkan di yayasan yang secara khusus bergerak untuk tujuan pendidikan.

Setiap individu tak lepas dari permasalahan baik masalah berat maupun masalah ringan. Adapun jenis masalah bermacam-macam. Winkel (1997) mengelompokkan masalah kepada: (1) masalah keluarga, (2) masalah sekolah/belajar, (3) masalah pengisian waktu senggang, dan (4) masalah dengan diri sendiri. Prayitno (1997)

\footnotetext{
Telp dan/atau Alamat Email Koresponden :

${ }^{1}$ Email: yusidaimran@ymail.com
} 
Jurnal Konseling dan Pendidikan

memilah masalah menjadi dua kelompok, yaitu masalah umum dan masalah belajar. Masalah-masalah yang bersangkut paut dengan kegiatan belajar mencakup kondisi prasyarat penguasaan materi pelajaran (P), ketrampilan belajar (T), sarana belajar (S), kondisi diri (D) dan kondisi lingkungan fisik dan sosio emosional (L). Masalah umum mencakup sepuluh bidang masalah, yaitu masalah jasmani dan kesehatan (JDK), masalah diri pribadi (DPI), masalah hubungan sosial (HSO), masalah ekonomi keuangan (EDK), masalah karir dan pekerjaan (KDP), masalah pendidikan dan pengajaran (PDP), masalah hubungan muda-mudi (HMM), masalah keadaan hubungan keluarga (KHK), masalah agama, nilai dan moral (ANM), masalah waktu senggang. (WSG).

Dari berbagai jenis masalah yang ada, telah banyak dilakukan penelitian, namun tempatnyanya berbeda seperti penelitian yang pernah dilakukan Eni Yusnita Lubis tentang masalah-masalah belajar dan pendapat siswa tentang aplikasi high-touch dan high-tech dalam proses pembelajaran, yang dilakukan pada peserta didik di sekolah. Penelitian Jum Anidar tentang masalah-masalah diri pribadi mahasiswa dan upaya menanganinya di Fakultas Tarbiyah Institut Agama Islam Imam Bonjol Padang, yang dilakukan pada peserta didik di Perguruan Tinggi. Penelitian Afrizen, tentang masalah hubungan muda-mudi siswa dan peranan guru pembimbing studi pada SMA Negeri I Sumpur Kudus. Masih ada penelitian lainnya tentang masalah-masalah peserta didik, tetapi untuk melihat masalah peserta didik di yayasan belum banyak, sehingga penulis tertarik untuk melakukan penelitian tentang masalah di yayasan itu, yang mana permasalahan dan penanganannya akan berbeda, mengingat Yayasan Asrul Bakar dalam hal ini disingkat (YAB) adalah yayasan sosial keagamaan, yang juga menangani orang-orang yg bermasalah dalam bidang kesehatan rohani.

Setelah melakukan pengamatan/ observasi awal dan wawancara pada bulan Oktober 2010, diperoleh keterangan dari pengurus yayasan bahwa Yayasan "Asrul Bakar" merupakan pusat rehabilitasi mental, serta pengembangan bidang kerohanian. Keunikan dari yayasan tersebut menampung masyarakat yang berusia ada yang lebih dari 25 tahun, yang usianya telah tergolong dewasa. Jumlah mereka (yang tinggal di YAB) sebanyak 25 orang, beberapa orang di antara mereka mengalami putus sekolah pada tingkat SD, SMP maupun SMA, dan selebihnya ada yang hanya menyelesaikan bangku pendidikan pada tingkat SD, SMP, SMA (putus lanjut), selain itu ada pula anak asuh yang sampai pada bangku Perguruan Tinggi.

Di samping gambaran positif tentang fasilitas dan pelayanan yayasan tersebut di atas, fenomena juga memperlihatkan bahwa keberadaan mereka (klien) di yayasan itu ada yang mempunyai permasalahan tertentu. Keadaan ekonomi pada umumnya kurang memadai, hubungan dengan orang tua kurang baik. Ada yang mempunyai masalah sosial, seperti kenakalan remaja, masalah pendidikan seperti putus sekolah, dan masalah pekerjaan yang belum tetap, dan yang menjadi focus penelitian adalah masalah yang menyangkut kesehatan mental bagi orang-orang yang mengalami stress dan depresi, itupun baik internal maupun eksternal dari subjek yang bersangkutan. Klien belum mendapat pelayanan yang optimal ketika mereka bermasalah, demikian pula dengan orang tua mereka sepertinya tidak dapat memecahkan masalah yang dihadapi anak-anaknya, sehingga klien tersebut tidak tahu harus bagaimana bersikap untuk menyelesaikan permasalahan yang dihadapinya, sehingga dikhawatirkan menimbulkan dampak serta akibat negatif dari permasalahan yang tak terpecahkan secara benar. Kesemuanya itu dapat mengganggu kondisi psikologis mereka, sementara itu pemecahan masalah terkadang tidak memadai untuk terentaskan, sering kali masalah-masalah itu "menguap" begitu saja seiring waktu yang berlalu. Sebagian masalah bahkan sepertinya "terpecahkan" setelah yang bersangkutan mengalami konflik berkepanjangan.

Untuk solusinya sejauh ini belum ada penanganan khusus dari yayasan tempat mereka bernaung, ditanggapinya masalah tersebut baru berupa nasehat dan "siraman rohani" serta sedikit bantuan materi dari pembina dan pengurus yayasan. Adapun peranan keluarga dan pengasuh dalam yayasan belum optimal. Dalam hal ini penyelesaian masalah belum mereka lakukan secara terorganisir sehingga hasilnya belum optimal, dengan masih adanya masalah yang berlarut-larut dan tidak tuntas dalam penanganannya. Solusi dan jalan keluar sudah diusahakan hanya saja proses konseling seperti layaknya ilmu dalam Bimbingan Konseling belum dilaksanakan secara keseluruhan.

Memperhatikan gambaran di atas, hal-hal yang perlu diperhatikan adalah: masalah-masalah apa saja yang dihadapi klien di yayasan saat ini? Apa saja sebab dan akibat masalah tersebut? Bagaimana menanganinya? Apa peranan keluarga dan pengasuh dalam yayasan? Hal yang tak kalah pentingnya adalah bagaimana sikap klien itu ketika mereka bermasalah? 


\section{METODOLOGI}

Penelitian ini dilaksanakan dengan menggunakan pendekatan deskriptif yang mengandung unsur data kualitatif dan kuantitatif. Cohen dan Marison (dalam Riska,1999:24) A. Muri Yusuf (2005:82). Secara umum penelitian ini ditujukan untuk mendeskripsikan permasalahan anak asuh dengan kondisi atau keadaan anak-anak asuh sekarang dalam kaitannya dengan masalah yang dialami anak asuh sebelumnya, dalam hal ini peneliti juga menggunakan instrumen pengukuran berupa AUM Umum baik untuk SMA, mahasiswa, maupun AUM masyarakat disesuaikan dengan umur anak asuh yang berada di Yayasan Asrul Bakar, untuk mengetahui masalah berat yang dialami akan didalami dengan layanan informasi dan layanan konseling individual.

\section{HASIL DAN PEMBAHASAN}

\section{Pelaksanaan Layanan Informasi}

\section{Perencanaan}

Sebelum melaksanakan layanan informasi terlebih dahulu penulis melakukan perencanaan yang menyangkut klien berhubungan dengan identifikasi kebutuhan akan informasi bagi calon peserta layanan, menetapkan materi informasi, menetapkan subjek sasaran layanan, menetapkan nara sumber, menyiapkan prosedur, perangkat dan media layanan serta menyiapkan kelengkapan administrasi.

Untuk mengetahui lebih rinci tentang anak asuh, maka akan diungkapkan data klien untuk kepentingan layanan informasi yang akan diberikan. Dalam hal ini subjek sasaran layanan adalah 5 orang anak asuh yang mengalami masalah berat, sedangkan nara sumber adalah penulis sendiri, tempat pelaksanaan di ruang TK komplek yayasan, yang di dalamnya telah tersedia kursi dan meja serta perangkat tulis dan buku-buku untuk menunjang pelaksanaan layanan informasi.

\section{Pelaksanaan}

untuk pelaksaan layanan informasi penulis mengorganisasikan kegiatan layanan sesuai dengan permasalahan yang dihadapi masing-masing anak asuh, kemudian mengaktifkan peserta layanan dengan cara memberikan informasi yang dibutuhkan serta membuka kesempatan tanya jawab pada mereka selanjutnya penulis mengoptimalkan penggunaan metode diskusi dan media seperti buku-buku bacaan yang sesuai dengan masingmasing kebutuhan anak-anak asuh.

\section{Pelaksanaan Layanan Konseling Individual}

Setelah melakukan observasi, pengadministrasian AUM serta dilakukan layanan informasi pada 5 orang anak asuh yang mengalami masalah berat, peneliti melihat bahwa layanan konseling yang telah mereka peroleh di yayasan sesungguhnya sudah ada namun belum memenuhi kriteria atau prosedur yang sesuai dan disyaratkan dalam ilmu bimbingan dan konseling, yang mana diberikan oleh pengurus maupun pembina dalam upaya mengentaskan permasalahan yang dialami anak asuh, itu semua belumlah cukup sehingga mereka belum merasa puas dan pemecahan masalahnya belumlah tuntas. Pada anak asuh diberikan layanan di yayasan baru berupa nasehat, petunjuk, dan perintah. Jalan keluar dan solusinya belum memadai, adapun layanan informasi seadanya seperti petunjuk saja tanpa referensi, begitu pula konseling individual belum terarah sesuai prosedur, sehingga perlu kiranya dilakukan layanan-layanan konseling yang tepat, untuk dapat mengentaskan masalah anak asuh secara tuntas. 
Jurnal Konseling dan Pendidikan

\section{KESIMPULAN SARAN}

\section{Kesimpulan}

Berdasarkan temuan dan pembahasan, dapat ditarik kesimpulan yaitu: Kondisi anak-anak asuh di YAB sebagian mengalami berbagai permasalahan yang terungkap melalui AUM-Umum dan wawancara. Sebagian besar mengalami masalah dalam bidang pendidikan, karir dan pekerjaan, hubungan sosial kemasyarakatan serta ekomomi dan keuangan. Pelayanan konseling khususnya layanan informasi dan layanan konseling peorangan, bagi anak-anak asuh di YAB dapat dilaksanakan untuk membantu anak-anak asuh dalam pengentasan masalah mereka serta dirasakan sangat bermanfaat. Kedua jenis layanan konseling ini dapat mengembalikan kehidupan efektif sehari-hari mereka.

\section{Saran}

Anak-anak asuh hendaknya memperoleh kesempatan mendapatkan layanan konseling yang disediakan oleh yayasan, yang terbukti efektif mengentaskan permasalahan mereka. Pembina dan pengurus yayasan hendaknya menjadikan layanan bimbingan dan konseling sebagai kegiatan tetap dan khusus dalam penanganan anak-anak asuh dalam yayasan, serta menyediakan sarana dan prasarana untuk ketersedian dan kelancaran pelaksanaan pelayan konseling. Program Studi Bimbingan dan Konseling perlu menyiapkan calon-calon konselor yang kompeten untuk ditugaskan di yayasan mengingat kekhususan kondisi yayasan pada umumnya serta sarana dan prasarana yang terbatas.Dinas sosial hendaknya memperhatikan dan dapat memfasilitasi kebutuhan yayasan, khususnya yang berhubungan dengan pelayanan konseling bagi anak asuh yayasan.

\section{DAFTAR PUSTAKA}

A. Muri Yusuf. 2005. Metodologi Penelitian. Padang: UNP Press Padang.

Departemen Sosial. 2004. Tentang Pelayanan pada Panti Sosial. Jakarta

Dinas Kesejahteraan Sosial . 2003. Profil Data Anak Terlantar Kota Padang. Padang

Prayitno dan Erman A.1999. Dasar-Dasar Bimbingan Konseling. Edisi Revisi . Jakarta: Rineka.

Prayitno. Dkk.1997. Pedoman AUM Umum. Depdikbud: Dirjen Dikti.

. 1998. Konseling Panca Waskita : Konseling Eklektik. Padang: Prodi BK FIP IKIP Padang.

Riska Ahmad. 1999. Studi tentang Pengungkapan Hasil Layanan Konseling Perorangan. Tesis. Tidak Dipublikasikan. Padang: UNP.

Shertzer, B \& Stone, S.C.1980. Fundamentals of counseling. 3 ed. Boston: Houghton Miflin Company.

Winkel. 1997. Bimbingan dan Konseling di Institusi Pendidikan. Jakarta: Gramedia. 